\title{
Geothermal resources and reserves in Indonesia: an updated revision
}

\author{
A. Fauzi \\ PT. Geo Power Indonesia, Menara Palma \#15-02A-B Kuningan, 12950 Jakarta, Indonesia \\ Correspondence to: A. Fauzi (fauziamir2000@yahoo.com)
}

Received: 21 June 2014 - Revised: 6 January 2015 - Accepted: 20 January 2015 - Published: 17 February 2015

Abstract. More than 300 high- to low-enthalpy geothermal sources have been identified throughout Indonesia. From the early 1980s until the late 1990s, the geothermal potential for power production in Indonesia was estimated to be about 20000 MWe. The most recent estimate exceeds 29000 MWe derived from the 300 sites (Geological Agency, December 2013).

This resource estimate has been obtained by adding all of the estimated geothermal potential resources and reserves classified as "speculative", "hypothetical", "possible", "probable", and "proven" from all sites where such information is available. However, this approach to estimating the geothermal potential is flawed because it includes double counting of some reserve estimates as resource estimates, thus giving an inflated figure for the total national geothermal potential.

This paper describes an updated revision of the geothermal resource estimate in Indonesia using a more realistic methodology. The methodology proposes that the preliminary "Speculative Resource" category should cover the full potential of a geothermal area and form the base reference figure for the resource of the area. Further investigation of this resource may improve the level of confidence of the category of reserves but will not necessarily increase the figure of the "preliminary resource estimate" as a whole, unless the result of the investigation is higher.

A previous paper (Fauzi, 2013a, b) redefined and revised the geothermal resource estimate for Indonesia. The methodology, adopted from Fauzi (2013a, b), will be fully described in this paper.

As a result of using the revised methodology, the potential geothermal resources and reserves for Indonesia are estimated to be about $24000 \mathrm{MWe}$, some 5000 MWe less than the 2013 national estimate.

\section{Introduction}

Much of the Indonesian Archipelago is situated on the boundary of the Indo-Australian and the Eurasian tectonic plates. Numerous active volcanoes are associated with this plate boundary, stretching from Sumatera to Java, Bali and Maluku up to Sangihe Island, resulting in many highenthalpy geothermal resources in these areas.

There are more than 177 volcanic centres in the Archipelago, of which about 88 bear evidence of fumarolic and solfataric activity (Radja, 1990). Reconnaissance studies carried out since the mid-1960s have found in excess of 300 sites as potential high- to low-enthalpy geothermal sources.

The first national geothermal energy potential estimate was reported to be about 16000 MWe (Radja, 1990). This was later revised by Pertamina to be about $20000 \mathrm{MWe}$ (Fauzi et al., 2000; Pertamina, 2005). A short time later, at the 2000 World Geothermal Congress, the government of Indonesia released an estimate of the national geothermal energy potential to be approximately $27000 \mathrm{MWe}$. The most recent estimate of geothermal potential exceeds $29000 \mathrm{MWe}$ (Geological Agency and Ebtke, December 2013).

This paper presents the results of an updated revision of the geothermal energy potential of Indonesia based on the most updated data (Geological Agency, December 2013). The revision uses a new summation methodology which was described in Fauzi (2013a, b) by using the 2008 geothermal potential data. The new summation methodology will be fully described in this paper. 


\section{Definitions}

In general, geothermal resources are defined as thermal energy beneath the earth at depths shallow enough to be tapped/extracted economically and legally by drilling at a specific time. Geothermal reserves are defined as that portion of the geothermal resource that is commercially extractable. Below are examples of specific definitions.

Geothermal resources: the estimates of geothermal potential determined on the basis of limited data and yet to be proven as potential reserves (SNI, 1998).

Geothermal resource is a term used to define a quantity of geothermal heat that is likely available if certain technologic and economic conditions are found in the future (specified) time (Pertamina, 2005).

A geothermal resource is a geothermal play which exists in such a form, quality and quantity that there are reasonable prospects for eventual economic extraction. Resources are known, estimated or interpreted from specific geological evidence and knowledge. Geothermal resources are subdivided, in order of increasing geological confidence, into categories of inferred, indicated and measured (Australian Geothermal Code, 2010).

Speculative resources: the estimate based on the presence of geothermal surface manifestations and other signs of heat flow (modified from Pertamina, 2005). (Note: speculation is about something that cannot be definitely proven, i.e. theoretical.)

Hypothetical resources: determined from regional geologic surveys and geochemistry of thermal features. Storedheat calculations and estimates are used for resource sizing (modified from Pertamina, 2005). (Note: in science, a hypothetical conclusion is drawn before all the facts have been discovered and adopted for the time being as a guide to further investigation.)

Geothermal reserves: total heat content stored in the subsurface that is economically recoverable and estimated using the geosciences survey as a tool (SNI, 1998).

Geothermal reserves consist of identified economic resources that are recoverable at a cost that is competitive now with other commercially developed energy sources. Reserve estimates are calculated based on well data and or geoscientific data (modified from Pertamina, 2005).

A geothermal reserve is that portion of an indicated or measured geothermal resource that is deemed to be economically recoverable after the consideration of both the geothermal resource parameters and modifying factors. These assessments demonstrate at the time of reporting that energy extraction could reasonably be economically and technically justified (Australian Geothermal Code, 2010).

Possible reserves: the geothermal energy potential in the subsurface is estimated by using integrated surface geoscientific survey data (modified from Pertamina, 2005).

Probable reserves: the geothermal energy potential in the subsurface is estimated by using integrated surface geoscien- tific survey data and the result of one discovery well (modified from Pertamina, 2005).

A probable geothermal reserve is the economically recoverable part of an indicated or, in some circumstances, a measured geothermal resource (Australian Geothermal Code, 2010).

Proven reserves: the geothermal energy potential in the subsurface is estimated by using integrated surface geoscientific survey works with reasonable certainty and includes one discovery well and two producing delineation wells to obtain data on the subsurface parts of the system (modified from Pertamina, 2005).

A proven geothermal reserve is the economically recoverable part of a measured geothermal resource. It includes a drilled well, the deliverability of which has been demonstrated in commercial production for the assumed lifetime of the project with a high degree of confidence (Australian Geothermal Code, 2010).

Cut-off temperature: minimum temperature required for wells to self-discharge in convective geothermal development. For pumped flows, the minimum economic reservoir fluid temperature for commercial energy extraction is based on the estimated temperatures from surface geochemistry (Australian Geothermal Code, 2010).

Note that cut-off temperature is the minimum temperature below which it is not economic to include the reservoir volume as part of the resource. The cut-off temperature typically used by geothermal scientists and engineers is $\sim 180^{\circ} \mathrm{C}$ for the purpose of generating electricity using a "conventional steam turbine". This figure has also been discussed in Australian Geothermal Code, 2010 - p. 18-19.

The definitions above that are quoted from several sources are only very slightly different between themselves. The difference showed in the terminology used; for example in Australian Geothermal Code the categories "inferred", "indicated" and "measured" were used, and in others the terms "speculative", "hypothetical", "possible", "probable" and "proven" were used. This sequence is given in order of increasing geological confidence. Furthermore, there is a reasonable degree of consistency between them with respect to the definition of "resources" versus "reserves".

\section{History of resources estimation}

The estimates of resource and reserve potential of geothermal energy in Indonesia has gone through three phases.

In the First Phase, from the early 1980s until the late 1990s, estimates of resources and reserves were predominantly carried out by the Directorate of Geology \& Mineral Resources (in Suryantoro, 2000, 2005) and Pertamina (2005). In this phase, the attention was paid on the high enthalpy resources.

In the Second Phase, the estimates were made by the Director General of Geology and Mineral Resources (in 
Table 1. Indonesia geothermal resources and reserves: December 2013 status.

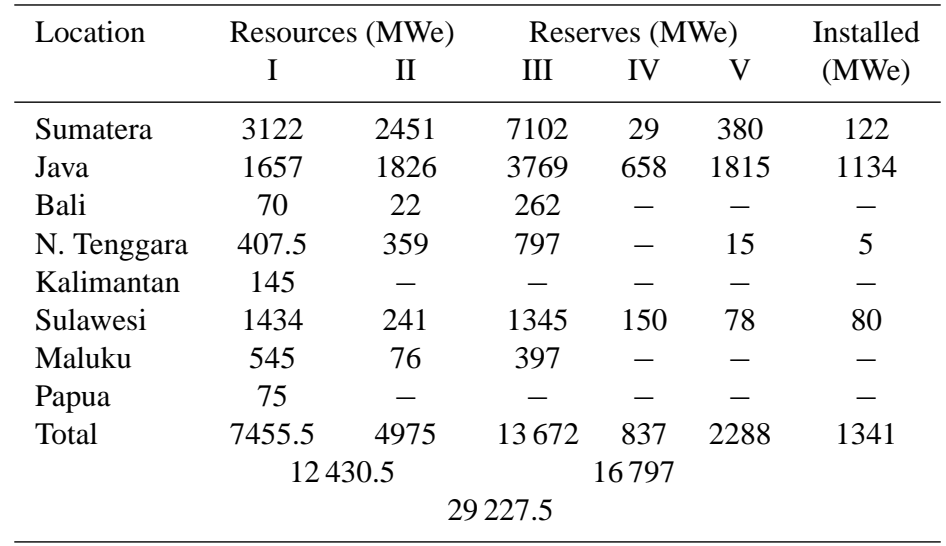

Geological Agency \& Ebtke (December 2013)

I - speculative; II - hypothetical; III - possible; IV - probable; V - proven.

Suryantoro, 2000, 2005), and first released at the 2000 World Geothermal Congress.

For the third phase, the estimates of resources and reserves were carried out by the Geological Agency of Indonesia, and published in API NEWS (2013) and in Geological Agency (2013).

Within the last two decades, all the prospects/resources from very low to high enthalpy have become the focus of further investigation. The results are shown in Table 1.

Volumetric method resource estimation, which is commonly used within the geothermal industry, has been applied to have the result as shown in Table 1 (Munandar, personal communication, 2004). It is considered that the volumetric estimation is the only one of the methods consistently applicable for resource estimation at an early stage in Indonesia.

The most recent geothermal resource figures were obtained by adding all the numbers from all of the categories speculative, hypothetical, possible, probable and proven as shown in the published information (Table 1). In the case of no new summation methodology being adopted, as proposed in Fauzi $(2013 \mathrm{a}, \mathrm{b})$, it is almost certain that there will be no more significant new prospects inventory; it is highly likely that the resource figures of $29000 \mathrm{MWe}$ (Table 1) will be constant with time in the future.

\section{Reassessment of the resources and reserves}

Currently, the geothermal potential classification process includes estimating the geothermal potential of a prospect area in one of five categories defined above from a "speculative resource" (the least certain category of geothermal potential) to a "proven reserve" (the most reliable estimate of an area's geothermal potential).

The preliminary speculative resources category of resources should cover the full potential of the area and form the base reference figure for the resource of the potential geothermal field. Eventually, further investigation of this resource may allow parts of the speculative resource to be upgraded to proven reserve. However, the total "resource capacity" does not increase in this upgrade (unless, of course, the estimated area of the geothermal field resource is increased).

Where detailed geological, geochemical and geophysical surveys are conducted over the resource area, then that part of the geothermal resource may be upgraded to the category of "possible reserve". Further studies and surveys including at least one exploration well must be able to prove the existence of a high-temperature fluid that can be used for producing electric power. This will allow that part of the resource to be categorized as "probable reserves". Again this does not make an addition to the possible reserves or the total resource. Additional produced exploration wells that can provide a threedimensional model of the geothermal resource can result in the estimate being upgraded in the area of the drilling and model to proven reserves. Again, the estimate of the proven reserves does not increase the estimate of the geothermal resource as a whole as "geothermal reserves" are defined as that portion of the geothermal resource that is commercially extractable.

Thus, all activities (geoscientific surveys and drilling) that follow an initial resource estimate of the geothermal potential are tools to prove, with increasing certainty, the existence of geothermal energy stored in the reservoir rocks in the form of high-temperature fluid. Once a geothermal resource is established, any further estimates (that upgrade part of the resource to a hypothetical resource or a possible/probable/proven reserve) should not be added to the total resource capacity.

The previous practice of "summation" as depicted in Table 1 does not give a correct estimate as it leads to a greater estimate of the geothermal potential than is actually present. Based on this fact, the total summation methodology as a resource estimation tool needs to be improved. 
Table 2. Geothermal resources and reserves: examples of proposed methodology using selected areas.

\begin{tabular}{|c|c|c|c|c|c|c|}
\hline \multirow[t]{2}{*}{ Location } & \multicolumn{2}{|c|}{ Resources (MWe) } & \multicolumn{3}{|c|}{ Reserves (MWe) } & \multirow{2}{*}{$\begin{array}{c}\text { Installed } \\
\text { (Mwe) }\end{array}$} \\
\hline & I (A) & II $(\mathrm{B})$ & III (C) & IV (D) & $\mathrm{V}(\mathrm{E})$ & \\
\hline Sibayak & - & 34 & 35 & - & 30 & 2 \\
\hline Sibayak & 35 & 34 & 35 & - & 30 & 2 \\
\hline Dolok Marawa & 100 & - & 40 & - & - & - \\
\hline Dolok Marawa & 100 & - & 40 & - & - & - \\
\hline Cubadak & 73 & - & 100 & - & - & - \\
\hline Cubadak & $73 / 100$ & - & 100 & - & - & - \\
\hline Awibengkok & - & - & 110 & 110 & 375 & 375 \\
\hline Awibengkok & $-/ 375$ & - & 110 & 110 & 375 & 375 \\
\hline Kamojang & - & - & - & 300 & 260 & 140 \\
\hline Kamojang & $-/ 300$ & - & - & 300 & 260 & 140 \\
\hline Darajat & - & - & 160 & 150 & 300 & 255 \\
\hline Darajat & $-/ 300$ & - & 160 & 150 & 300 & 255 \\
\hline \multirow[t]{2}{*}{ Total } & $173 / 1210$ & 34 & 445 & 560 & 965 & - \\
\hline & \multicolumn{6}{|c|}{$2177 / 1210$} \\
\hline
\end{tabular}

Original data from Geological Agency (2013). I - revised speculative resource as the whole resource; II hypothetical; III - possible; IV - probable; V - proven.

Table 3. Revised total geothermal resources and reserves in Indonesia.

\begin{tabular}{lcccccc}
\hline Location & \multicolumn{2}{c}{ Resources (MWe) } & \multicolumn{2}{c}{ Reserves (MWe) } & Installed (MWe) \\
& I & II & III & IV & V & \\
\hline Sumatera & 11054 & 2451 & 7102 & 29 & 380 & 122 \\
Java & 7242 & 1826 & 3769 & 658 & 1815 & 1134 \\
Bali & 327 & 22 & 262 & - & - & - \\
N. Tenggara & 1399 & 359 & 797 & - & 15 & 5 \\
Kalimantan & 145 & - & - & - & - & - \\
Sulawesi & 2842 & 241 & 1345 & 150 & 78 & 80 \\
Maluku \& Papua & 1011 & 76 & 397 & - & - & - \\
Total & 24020 & 4975 & 13672 & 837 & 2288 & 1341 \\
& & & 24020 & & & \\
\hline
\end{tabular}

Resummation speculative resource based on Geological Agency data (December 2013)

I - revised speculative resources as the whole resources; II - hypothetical; III - possible; IV - probable; V - proven.

In addition, the resource numbers shown in Table 1 are the result of using different cut-off temperatures. In the case of a country-wide resource assessment, like Indonesia, assumptions for electricity generation using a conventional steam turbine power plant should use a single cut-off temperature typically $\sim 180^{\circ} \mathrm{C}$. In fact, the estimate of 29000 MWe potential resource in Indonesia used variable cut-off temperatures, which ranged from 90 to $180^{\circ} \mathrm{C}$ (SNI, 1999). This approach should be avoided.

\section{Suggested approach}

The initial estimation of the geothermal energy potential of an area is usually done through the study of literature and a site visit to the area. This estimation is classified as a resource and placed into the speculative and/or hypothetical category. Further study using geoscientific surveys and exploration drilling can improve the level of confidence to the category of reserves that consists of possible, probable and proven reserves.

The initial estimate that classifies the geothermal potential as a speculative resource, and the estimate using geoscientific surveys as a possible reserve, should be the main focus in terms of determining how large the geothermal energy resources are in a region. The initial estimates and the geoscientific survey will substitute one another unless the last two classifications, probable and proven reserves, prove higher than possible reserves and speculative resources. For example, see Table 2 for Darajat, Awibengkok and Kamojang fields. The proven reserves from the first two fields are the figures for the total resources of the fields. And the probable reserves from Kamojang are the total resources of field.

The estimate of a possible reserve may be lower or higher than a speculative resource. If the estimate of possible reserve remains lower than the estimated speculative resources, then the initial estimate remains being a benchmark for the calcu- 
Table 4. Classification of geothermal resources in Indonesia: based on estimated subsurface temperature resource groups.

\begin{tabular}{lcc}
\hline Location & \multicolumn{2}{c}{ Resource classification (MWe) } \\
& $\begin{array}{c}\text { Low enthalpy } \\
<100 \text { to } 190^{\circ} \mathrm{C}\end{array}$ & $\begin{array}{c}\text { High enthalpy } \\
>190^{\circ} \mathrm{C}\end{array}$ \\
\hline Sumatera & & \\
\hline Aceh & 520 & 782 \\
North Sumatra & 170 & 2253 \\
West. Sumatra & 820 & 728 \\
Jambi + Riau & 224 & 778 \\
Bengkulu & 60 & 1005 \\
Bangka Belitung & 45 & - \\
South Sumatera & 555 & 987 \\
Lampung & 409 & 1718 \\
\hline Java & & \\
& & 385 \\
Banten & 148 & 3261 \\
West Java & 1131 & 954 \\
Central Java & 350 & 1158 \\
East Java \& Bali & 182 & 537 \\
Nusa Tenggara & 862 & - \\
Kalimantan & 145 & 1146 \\
Sulawesi & 1696 & 442 \\
Maluku \& Papua & 569 & 164 \\
Total & 7886 & \\
\hline
\end{tabular}

lation of total resources for the region. On the other hand, if the estimate obtained from the results of further investigation is higher, this figure becomes the new reference number for the speculative resource (Table 2).

It is proposed that the resource calculation of a geothermal field not being estimated by summing all the numbers from speculative and hypothetical resources and from possible, probable and proven reserves. Thus the estimate for the calculation of total resources of an area is that estimate or figures recorded as the revised speculative resource (Table 2). As defined above, the hypothetical resources and all classes of reserves are that portion of the geothermal resources as resources in total (in Tables 2 and 3 as speculative resources).

In addition, the resources calculation should be treated differently for high- and low-temperature resources. For the high-temperature resources, a single cut-off temperature $\left(\sim 180^{\circ} \mathrm{C}\right)$ should be assumed for conventional steam power plants. And for the low-temperature resources for nonconventional steam power plants (i.e. binary plant) or other uses, the different approaches should be applied.

Notes:

1. Sibayak: if $(C)>(B)$ or $(C)>(A)$, then the number in (C) should be transferred to (A) or (B) and be the same as the reference that is used in summation as a resource in total.
2. Dolok Marawa: if $(C)<(A)$, then the number in $(A)$ is the reference without any changes used in summation as a resource in total.

3. Cubadak: if $(C)>(A)$, then the number in $(C)$ should be transferred to (A) to be used in summation as a resource in total.

4. Awibengkok (Salak): if $(E)>(A)$, then the number in (E) should be transferred to (A) to be used in summation as a resource in total. Similar for Darajat.

5. Kamojang: if $(D)>(A)$, then the number of the potential in (D) should be transferred to (A) to be used in summation as a resource in total.

6. The resource calculation of a geothermal field is not estimated by summing all the numbers from speculative (A) and hypothetical (B) resources and from possible (C), probable (D) and proven (E) reserves.

7. Thus the total resource as a whole resource in this example is $1210 \mathrm{MWe}$.

8. The figure of the resource calculation using current methodology by summing all the numbers is 2177 MWe.

9. The dashes or slashes, especially in (A) entries, mean that the original estimate of total resources of each prospect/field is not available.

10. Pertamina (2005) proposed at the early stage that all the new resources have the speculative resource of $250 \mathrm{MWe}$. Assumed that each of them is considered to have an area of $20 \mathrm{~km}^{2}$ and the recoverable resource has a power density at $12.5 \mathrm{MWe} \mathrm{km}^{-2}$. In future, this proposal should be considered in order to avoid the dashes within the (A) entries.

11. The bold numbers are the revised estimates (see texts)

Using a more realistic methodology as described in Table 2, the geothermal resource potential of Indonesia is revised down to be approximately $24000 \mathrm{MWe}$, some 5000 MWe less than the 2013 national estimate such as that summed up and concluded in Table 3. For example, the original total resource for Sumatera, by summing up all of column I to V in Table 1, is $13084 \mathrm{MWe}$; after revision it is $11054 \mathrm{MWe}$ in Table 3. Thus, the figures in column I are the result after being revised from figures present in Table 1.

It is interesting to note that about $8000 \mathrm{MWe}$ out of $24000 \mathrm{MWe}$ resources are classified as non-electrical-grade $\left(<100^{\circ} \mathrm{C}\right)$ to low-temperature $\left(150\right.$ to $\left.190^{\circ} \mathrm{C}\right)$ resources as defined by Sanyal (2005) (Table 4).

The cut-off temperature used by geothermal scientists and engineers typically is $\sim 180^{\circ} \mathrm{C}$. Based on this cut-off temperature, these non-electrical-grade $\left(<100^{\circ} \mathrm{C}\right)$ to lowtemperature $\left(150\right.$ to $\left.190^{\circ} \mathrm{C}\right)$ resources are not efficiently 
converted into power (MWe). Consequently, the figure of $8000 \mathrm{MWe}$ is flawed and should be reviewed. The real figure could be less than $8000 \mathrm{MWe}$ and partly intended for direct use and/or electricity through binary technology or other.

\section{Conclusions}

The previous estimate of the geothermal resources of Indonesia included double counting of some reserves estimates as resources estimates, thus giving an inflated figure of the total national geothermal resource potential.

Using a more realistic methodology proposed in Fauzi $(2013 \mathrm{a}, \mathrm{b})$, where this double counting is removed, the geothermal resource potential of Indonesia is revised down to approximately $24000 \mathrm{MWe}$. This is some $5000 \mathrm{MWe}$ less than the previous 2013 national geothermal resource estimate of $29227.5 \mathrm{MWe}$.

Acknowledgements. The author thanks Kenneth B Alexander and Robert King for their valuable comments.

Edited by: G. Beardsmore

Reviewed by: J. Lawless and G. Giudetti

\section{References}

API News-Sikumbang, Let's Investing Together on Geothermal; in API (Indonesian Geothermal Association) News No. 8 - October 2012, p.5., 2012.

Australian Geothermal Code Committee: Geothermal Lexicon For Resources and Reserves Definition and Reporting, Edition 2, Adelaide, 2010.

Directorate General of New Energy: Renewable and Conservation Energy (Ebtke), Profil Potensi Panas Bumi Indonesia, 2012.

Fauzi, A.: Geothermal development in Indonesia: An overview; Geothermia, Rev de Geoenergia, 14, 147-152, 1998.
Fauzi, A.: A proposed new methodology for estimating geothermal resources and reserves in Indonesia; in Petrominer Magazine No. 5, May 2013, 64-65, 2013a.

Fauzi, A.: Geothermal Resources and Reserves in Indonesia: A Revision; in: Proceedings, 13th Indonesia International Geothermal Convention \& Exhibition 2013, Jakarta, Indonesia, 12-14 June, $2013 b$.

Fauzi, A., Bahri, S., and Akuanbatin, H.: Geothermal Development in Indonesia: An Overview of Industry Status and Future Growth; in Proc. World Geothermal Congress, 2000.

Geological Agency: (Badan Geologi Indonesia), Geothermal Area Distribution Map And Its Potential in Indonesia, Status Dec. 2013.

Pertamina: Pertamina Geothermal Development: Resources \& Utilization: Publication of Pertamina Geothermal Division, 2005

Radja, V. T.: Review of the Status of Geothermal Development and Operation in Indonesia; in Proceedings of the Geothermal Resources Council Transaction 1990, Kona, Hawaii, 20-24 August, 14, 127-145, 1990,

Sanyal, S. K.: Technical Paper: Classification of Geothermal Systems - A Possible Scheme, United States Department of Energy (Washington, D.C.), 2005.

SN:, Klasifikasi Potensi Energi Panas Bumi di Indonesia; Standar Nasional Indonesia-SNI 13-5012-1998-ICS 73.020, 1998.

SNI: Metode Estimasi Potensi Energi Panas Bumi di Indonesia; Standar Nasional Indonesia-SNI 13-6171-1999 ICS 73.020, 1999.

Suari, S. and Fauzi, A.: Geothermal Prospects in Sumatera; in Proc. Indonesian Petroleum Association, 20th Annual Convention, Oct. 1991-IPA, 91-21.21, 1991.

Suryantoro, S.: Challenges of Geothermal Development in Indonesia; in Proc. World Geothermal Congress, 2000.

Suryantoro, S., Dwipa, S., Ariati, R., and Darma, S.: Geothermal Deregulation and Energy Policy in Indonesia; in Proc. World Geothermal Congress, 2005.

Wahyuningsih, R.: Potensi dan Wilayah Kerja Pertambangan Panas Bumi di Indonesia: Subdit Panas Bumi, Kolokium Hasil Lapangan-DIM, 2005. 